\title{
Analýza pưsobení subjektivní reality na socializaci členů Občanského fóra v prǐhraničním městě Znojmě
}

\author{
Analysis of the influence of subjective reality on the socialisation \\ of members Civic Forum in the frontier town of Znojmo
}

DOI: 10.31577/EtnoRozpra.2021.28.2.03

\section{Jan Zerbst}

\begin{abstract}
The study examines socialization of the members of the Civic Forum in the regional town of Znojmo. The research focused on their recollections of the communist regime and was conducted through oral history interview and biographical interview. The results indicated that people's subjective reality took place in the surroundings of family and significant others who integrate individuals with society. Parents and mentors, who participated in upbringing, passed on their experiences to the narrators and presented opinions that contradicted the communist ideology.
\end{abstract}

\section{Key words}

subjective reality, socialization, communism, family, significant others, narrative

Klúčové slová

subjektivní realita, socializace, komunismus, rodina, významní druzí, narace

\section{Kontakt / Contact}

Mgr. Jan Zerbst, Fakulta humanitních studií Univerzity Karlovy, Pátkova 2137/5, 18200 Praha 8, Česká republika, e-mail: zerbstjan44@gmail.com

\section{Ako citovat' / How to cite}

Zebrst, J. (2021). Analýza působení subjektivní reality na socializaci členů Občanského fóra v př́hraničním městě Znojmě. Etnologické rozpravy, 28(2), 37-53. https://doi. org/10.31577/EtnoRozpra.2021.28.2.03 


\section{Úvod}

Nejobecnějším pohledem můžeme o pojmu socializace napsat, že je to komplexní proces, v jehož průběhu se člověk stává jako biologický tvor pomocí sociální interakce bytostí sociální a kulturní (Petrusek, 1999: 1012). Sociální interakce probíhají pro každého jedince v subjektivní a objektivní realitě. Objektivní realita je chápána jako institucionalizovaná společnost, která je vytvořena člověkem. Vytvořená objektivní realita následně pưsobí na člověka a dále jej utváří. Subjektivní realita je okolí, jenž uvádí jedince do společnosti, při němž dochází k internalizaci, osvojování objektivní reality. Subjektivní realita se většinou odehrává v prostředí rodiny a tzv. významných druhých, které zprostředkovávají a spoluutvářejí realitu jedince (Berger, Luckmann, 1999: 64, 130).

Expert na sociální pedagogiku Blahoslav Kraus (2001: 78-80) podotýká, že rodina je první sociální skupinou, která učí dítě přizpůsobovat se sociálnímu životu, osvojovat si základní návyky a způsoby chování běžné ve společnosti. Hovoříme tedy o socializačně-výchovné funkci rodiny. Socializací v rodině rozumíme především proces pưsobení rodiny na své členy v celém souhrnu jevů a procesů: ekonomických, sociálních, kulturních, mravních, estetických a zdravotních. Každá rodina nese své jedinečné morální hodnoty a znalosti, kterými si vytváří etická pravidla i pohled na svět. Oldřich Matoušek (2013: 4748) popisuje složku etických norem jako rodinný kodex. Ten slouží jako sklad zkušeností, jež je kdykoliv rodině k dispozici, aby rodinu provedl každodenním světem.

Rodina je tedy primárním místem socializace, nicméně rodiče nemají na vývoj svých dětí monopol. Průběh dospívání je také postupným procesem emancipace od rodičovského vlivu, jelikož přichází velmi brzy nová působení (hromadné sdělovací prostředky, škola atd.), které formují náš charakter (Možný, 2006: 166). Konkrétně se podíváme, jakou roli hráli ve vyprávěném příběhu tzv. významní druzí Bergera a Luckmanna (1999: 130). Významní druzí člověku zprostředkovávají objektivní realitu světa a v průběhu tohoto zprostředkovávání jedince pozměňují. Významní druzí vybírají na základě svých individuálních, osobních vlastností, jež se u nich v průběhu života vyvinuly, určité rysy tohoto světa v souladu se svým vlastním postavením ve společenské struktuře. Pohled Bergera a Luckmanna na významné druhé je poněkud př́krý, poněvadž ti mají býti socializované osobě vnuceni. Budu sledovat, jakým způsobem probíhal mentoring významných druhých na př́kladu mých narátorů. Pokud bychom pokračovali ve výkladu základních definicí, tak mentoring je blízký, individuální vztah, zpravidla mezigenerační, kdy zkušený mentor předává své zkušenosti mladšímu méně zkušenému chráněnci. Pomocí mentoringu dochází k osobnostnímu, vědomostnímu a sociálnímu rozvoji chráněnce a je součástí procesu jeho neformálního vzdělávání. Pro můj výzkum je nesmírně dưležité, že přirozenými mentory nejsou členové nukleární rodiny, otec a matka, ale přirozenými mentory lidí mohou být například jejich příbuzní, sousedé, učitelé nebo trenéři (Brumovská, Seidlová, 2010: 11-12).

Budu tedy sledovat předestřené příběhy významných osobností, které ovlivňovaly, mentorovaly narátory pro jejich budoucí život. Sféry, které narátoři předestřeli, Ize rozdělit do dvou skupin. První můžeme nalézt v úloze mentora s přímým vlivem na narátora a následně mýtus o člověku, s nímž neměli přímé spojení. U těchto příběhů se narátoři s významnými druhými identifikovali (Berger, Luckmann, 1999: 130). 


\section{Výzkumné prostředí a metodologie}

Výzkumný vzorek se rekrutoval z členů Občanského fóra př́íhraničního města Znojma. $\checkmark$ mém výzkumu vystupovalo deset respondentů (devět mužů, jedna žena). Pro výběr narátora, či narátorky bylo zásadní, aby vstoupil do OF a aktivně se zapojil do událostí na přelomu let 1989 až 1990. Finální výběr respondentů ovlivnily zdravotní stav (pacienti v terminálním stádiu onemocnění) a ochota poskytnout rozhovor (potenciální narátoři i narátorky odmítli poskytnout rozhovor kvůli nespokojenosti s vývojem polistopadové společnosti a neochotou se již společensky angažovat).

Před započetím rozhovoru byli respondenti informováni o cílech a průběhu výzkumu. Následně podepsali informovaný souhlas. Dva aktéři si před podepsáním souhlasu přáli, abych vypnul nahrávání, pokud mě o to požádají, což jsem učinil. Tyto informace jsem dále nevyužíval. Jednalo se o humorné glosy, které přišly narátorům nepatřičné, aby se objevily v závěrečné práci, či nepř́ijemné životní zkušenosti (vážné onemocnění, úraz nebo rodinné tragédie). Stejný př́stup jsem následně aplikoval i u vzpomínek zbylých narátorů a narátorky.

V rámci ochrany osobních údajů nezveřejňuji jména narátorů. Využil jsem možnosti anonymizace. $\mathrm{K}$ té jsem přistoupil, poněvadž před započetím rozhovoru respondenti podepisovali informovaný souhlas, kde si mohli vybrat, zdali chtěli své jméno zveřejnit. Vzhledem k tomu, že tři respondenti si práli své jméno anonymizovat, přistoupil jsem k utajení všech respondentů.

Abychom mohli sledovat fenomény subjektivní reality, musíme si uvědomit, že se budeme nacházet na poli mikrohistorie. Německý historik Hans Medick (1994: 40-48) považoval mikrohistorii za sestru dějin každodennosti (Alltagsgeschichte), díky níž šlo dešifrovat kategorie klasických dějin akcentací dějin osob, komunit a menších uskupení.

Mikrohistorická data získává orální historik pomocí rozhovorů. Využíval jsem zde dvou konkrétních technik. První je využití orálně-historického typu rozhovorů, jak jej vymezil nestor české orální historie Miroslav Vaněk. Ten doporučuje provést tř́fázový rozhovor: 1. část rozhovoru vede $\mathrm{k}$ volnosti narátorova vyprávění s občasným vstupem otázek odborníka; 2. rozhovor slouží k doptávání se nad určitými tématy; 3. rozhovor poskytuje prostor pro odborníkův výzkumný zájem (Vaněk, Mücke, 2011: 148-152). Druhá technika vedení rozhovoru vychází z myšlenek Fritze Schütze a jeho Das autobiographisch-narrative Interview. To se zaměřuje na volnost narátorova vyprávění a cilí formou doptávání na nejasná místa $v$ př́běhu, aby je narátor dovysvětlil. $V$ poslední fázi směřuje narátora $k$ abstraktním a zobecňujícím formám vlastního života (Schütze, 1983: 285). Tyto techniky jsou si sice podobné, nicméně každá akcentuje více jiný styl oral history. První technika je více návodná, vhodná tudíz pro dějiny každodennosti a technika Das autobiographisch-narrative Interview je př́hodná pro analýzu narativity narátorů. Každou z těchto technik vedení rozhovoru jsem následně využíval pro určitou typologii člověka. Orálně-historický rozhovor jsem používal při komunikaci s introvertním člověkem, kterému jsem pomáhal rozpomenout se na minulost. Das autobiographisch-narrative Interview se hodilo pro komunikaci s extrovertními narátory, u nichž bylo potřeba pouze občas udržet vyprávěcí linii př́běhu. 
Při rozhovorech vstupuje do popředí tzv. narativita. Tu zde budu sledovat pomocí príistupu psychologa Ivana Čermáka (2004: 17), jenž považuje narativitu v užším významu za proces vytváření př́iběhu. Ten se skládá z událostí, což implikuje, že je zakotven v konkrétnosti, každodennosti, časovosti a vystižení detailu. Narativita naskýtá badateli i možnost sledovat během vyprávění významovou strukturu, jenž organizuje věci do celků, tím přisuzuje význam jednání jednotlivcům a událostem podle jejich vlivu na celek.

Během orálně-historického výzkumu se tak projevuje, pokud bych využil myšlenek psychologa Vladimíra Chrze, narativní perspektiva narátora. Tato perspektiva odhaluje ve vyprávění souvislost a směřování a celkový tvar prožívaného života, který je tvořen figurami a zápletkami. Narativita je objektivem psychologů pouhou konstrukcí, při níž dochází k narátorovu ztvárněnému jednání prožitého života (Chrz, 2007: 7-11). Abychom mohli tedy podchytit vlivy subjektivní reality, musíme při výzkumu sledovat, jak narátor konstruoval události a jednání osob během rozhovoru.

\section{Rodina jako formující faktor pro fenomén zodpovědnosti}

Ve vzpomínkách narátorů se neustále vyskytoval jeden fenomén na pomezí sociologie a filozofie zodpovědnost. Filosof Hans Jonas (1997: 157) ve svém díle rozebíral podobnost zodpovědnosti mezi státníky a rodiči. Rodičovská odpovědnost v jeho pohledu se stává archetypem „vší odpovědnosti“, protože jejím úkolem je zajistit přirozený rozvoj dítěte. Prezentované vzpomínky narátorů na každodennost mládí ukázaly, že rodiče pro ně hráli zásadní úlohu při vštěpování odpovědnosti. Samotnou odpovědnost jakožto filozofický fenomén vnímá český filozof Jan Sokol (2010: 80) jako jednání, za něž jedinec musí nést vědomou zodpovědnost. Pěstování odpovědnosti se u narátorů rozvíjelo přes plnění povinností.

Narátor Vladimír Zatloukal měl mladšího sourozence, a tak od útlého věku byl veden k zodpovědnosti. Mladší sourozenec pro něho znamenal větší povinnosti. Musel dovést sourozence ze školy. Po př́chodu domů na něj čekal papír se seznamem domácích prací, které museli s bratrem vypracovat, než přišli rodiče ze zaměstnání, kvưli čemuž neměl př́liš prostoru pro klukovské roštárny, o nichž mluvil během rozhovoru. Toto narátor zdůrazňoval pomocí sloves „nemůžu“ a „musím“.

My jsme přišli ze školy, převlíkli jsme se s bráchou a najednou z venku pískot: „Pojd’, jdeme hrát ke kř́žku fotbal.“ „Já nemůžu, já musím udělat práci, kterou mi tady napsal tatínek!“ My jsme měli skutečně každý den zápřah. (narátor Vladimír Zatloukal, 25. 9. 2019)

Zároveň rodiče vedli oba mladíky k četbě literatury. Nejčastěji četli knižní sérii Knihy odvahy a dobrodružství (známé pod zkratkou KOD) z dílny Státního nakladatelství dětské knihy. Zamilovali si dílo Karla Maye, Hermana Melvilla a historické romány Waltera Scotta jako Ivanhoe, či Waverley (narátor Vladimír Zatloukal, 25. 9. 2019). Téma pracovitosti bylo u narátorů, kteří pocházejí z vesnice, spojené s prací kolem usedlosti. Tento jev popisoval i narátor Břetislav Jonáš: 
a furt byla práce. [...] Já jsem z početné rodiny, nás bylo sedm. (narátor Břetislav Jonáš, 19. 4. 2019)

Můžeme zde vidět paralelní zkušenosti narátorů, kteří museli od útlého dětství pracovat. Toto souviselo i s tím, jak narátor Břetislav Jonáš zpětně vnímal své rodiče. Když mi zprostředkoval, že pochází ze sedmi dětí, tak jsem konstatoval: „To už se dneska moc nevidí.“ $\checkmark$ tu chvíli došlo u narátora Břetislava Jonáše k dojetí, poněvadž shledal, že „moji rodiče jsou hrdinové." Tím se snažil zdůraznit jejich význam a lásku, kterou k nim pocitoval. Proto jsem se zeptal, jak si vlastně vzpomínal na tátu a mámu.

Dobře, velmi pracovití lidi od přŕrody moudř́, žádná ideologie, ale takoví... (dojetî) oni měli hodně práce, otec byl muzikant. On byl zemědělec. Bavilo ho vinařství, sázení, sady, kolem vína se staral. [...] A matka byla pracovitá, ta měla práci od rána do večera. (narátor Břetislav Jonáš, 19. 4. 2019)

Dialog mezi námi rámoval symbolický svět komunistického režimu, který působil na společnost, proto kromě pracovitosti se snažil zdůraznit jistou apolitičnost rodičů, které vykreslil pomocí sousloví „moudří, žádná ideologie.“ Určité politické ukotvení se u nich projevovalo nicméně tím, že neměli v oblibě komunistické partajníky.

Doma byl takový jako názor na komunisty, že jsou to nefakčenci, jo. Otec měl jednoho kamaráda, který byl sice komunista, naivní (důraz), který tomu věřil, hodnej člověk a tak dál, ale to byl jeden. (narátor Břetislav Jonáš, 19. 4. 2019)

Narátor zdůrazňoval, že mu rodiče již od útlého věku vykreslovali členy Komunistické strany Československa (dále jen KSČ) v negativním zabarvení, což při rozhovoru zdůraznil podstatným jménem „nefakčenci“ a zároveň popsal ve svém př́iběhu komunistického př́tele jeho otce pojmem „naivní, díky čemuž dával najevo, že nebylo zcela v pořádku vstupovat do KSČ.

Antikomunistický př́stup dokonce u rodičů narátora Břetislava Jonáše potvrdila jeho manželka, která se k nám v průběhu rozhovoru připojila a pomáhala mi tak rozvíjet rozhovor, jelikož její manžel patřil mezi introvertní typy narátorů. Předestřený příběh popisoval hodnocení okupační správy za Protektorátu Čechy a Morava s komunistickým režimem.

\section{Mně třeba jeho máti [maminka narátora Břetislava Jonáše] říkala: „Za Hitlera jsme se měli líp, bylo to demokratičtější než za komunistů. Za Hitlera byl pořádek. My jsme odevzdali jenom přebytky, aby jsme pro ty děcka měli [nějaký jídlo]. Nastoupili komunisti, my jsme museli [všechno] odevzdat, i když mi nezbylo [nic] pro vlastní děcka." (manželka narátora Břetislava Jonáše)}

Jo, tam nebyl takový negativní postoj na Němce, protože Němci jsou pořádní. (narátor Břetislav Jonáš, 19. 4. 2019)

Tuto vzpomínku Ize datovat do období narátorova ukončení studia, kdy se jeho manželka seznámila s rodinou narátora. Matka narátora Břetislava Jonáše tak dospělým osobám odkrývala svůj postoj vůči komunistickému režimu. Můžeme tedy vidět, že komunistické panství viděla negativně. Zatímco nacistická okupační správa zajištovala „pořádek“ v oblasti zajištování potravin, komunistický režim nenechával pro své občany dostatek 
obživy.

Větší porce povinností přicházely i po tragických rodinných událostech jako u narátorky Jany Jiráskové, jelikož po 2 . světové válce zemřel v jejím útlém věku otec.

\begin{abstract}
Žilo se v těch poválečných letech velice skromně. Potraviny byly ještě několik let na př́děl. Maminka dostávala po otcově smrti vdovský důchod a ten byl nízký. Naštěstí jsme měly v Citonicích zahradu s ovocnými stromy, pěstovaly brambory, zeleninu, zpočátku i pšenici pro slepice. [...] I já se od dětství podílela na zahradních pracích. [...] Díky tomu všemu jsem se naučila rýt, okopávat, sekat trávu srpem i kosou, řezat dřevo, přibíjet hřebíky, a když jsem některý hřebík ohnula, vytáhla jsem ho kleštěmi a rovnala - nic se nevyhazovalo. (Paměti narátorky Jany Jiráskové, s. 7-8)
\end{abstract}

Aby narátorka Jana Jirásková spolu s její maminkou a staršími sestrami mohla vyžít po smrti otce, musely od začátku pracovat a pomáhat matce na malé usedlosti, což zdůraznila príslovcem „skromně“ a verbem „nevyhazovalo“. V jejím narativu nenajdeme žádné negativní prvky, naopak zpětně hodnotila dobu pozitivně, jelikož se „díky tomu všemu naučila“ manuálně pracovat a nebýt rozhazovačná.

Období, jež narátorka Jana Jirásková a narátor Břetislav Jonáš s manželkou vykreslovali, spadá v Československu do let 1945 až 1953, kdy po válce stále platil př́dělový systém. Ten vzniká obvykle $v$ dobách ekonomické nouze ( $v$ našem případě se jednalo o dozvuky 2. světové války), jež se projevuje nedostatkem jednoho či více druhů zboží. V Československu pak v rámci ideového boje docházelo k extrémním prípadům šikany oficiálních úřadů, protože prídělové lístky neudělovaly určitým skupinám osob, jakým byli soukromí podnikatelé, vesničtí boháči, důchodci, vyšší státní úředníci z let před rokem 1945, továrníci, bankéři, nepracující (Štěpek, 2008: 21-23).

Rodiče některých narátorů procházeli manželskou krizí, jako se např́klad stalo u rodiny narátora Václava Nováka. Tento pamětník se rozpovídal o rodinné každodennosti na můj popud, poněvadž dokončil příběh o jeho negativní zkušenosti s křestanskou výchovou na základní škole a já jej potřeboval dále rozpovídat.

Přišli jsme domů. Každý měl přidělený úkoly a když jsme si chtěli přivydělat nějakou korunu, [tak jsme] některým sedlákům chodili pást krávy, no jo, jenomže my jsme je osedlali, provaz okolo břicha a dělali jsme toreadory a závody. (smích) [...] Já jsem byl asi v pátý tř́dě. Jsme se přestěhovali do Podbořan a tam jsme bydleli a tam jsme se museli už starat. [...] Otec se s ní rozvedl, odešel pryč se starším bratrem do Rotavy u Sokolova. My jsme zůstali doma. (narátor Václav Novák, 1. 6. 2019)

Narátor Václav Novák byl jediným, kdo ve svém vyprávění otevřeně popisoval klukovské roštárny, přesto však jeho časová výplň kromě rodinné práce práce obsahovala i činnosti vedoucí k finančnímu přilepšení, protože si chodil „přivydělat“ k movitějším sedlákům. Při této príležitosti jsme nicméně nevědomky otevřeli narátorovu třináctou komnatu, jež mu byla nepř́ijemná - rozvod rodičů. Tuto událost však nebudu více konkretizovat, protože se jednalo pro narátora o velice citlivou vzpomínku, jež vyvolala silně zabarvené emoce. 
Za zmínku ovšem stojí, že s rozvodem bylo spojené i jeho finanční osamostatnění, poněvadž jeho matka nebyla schopná uživit své děti.

Narátor Václav Novák: Kolik mi bylo? Kolem 10, 11 let mi bylo. Já na to pamět nemám, ale vím, že jsem byl už trošičku větší kluk nějakej.

Zerbst Jan: To nevadí. Podle mě, když jste ročník narození 1942. A ještě v roce 1953 jste bydleli ve Vilémově a potom jste se odstěhovali do těch Libořic...

Narátor Václav Novák: To už se rodiče rozvedli...

Zerbst Jan: ...to už Vám mohlo být 13, 14.

Narátor Václav Novák: ...a Matka mě vzala sebou a povídá: ,Pojd’ se mnou!' Šli jsme na okresní výbor strany za tajemníkem a matka ho žádala, jestli by nebylo možný [požádat o] nějakou podporu, abychom dostali a že ona nás nemůže uživit, přestože my jsme makali, starali se. My jsme chovali králíky, my jsme je nejedli. My jsme vychovali králíky a príjížděl tam chlapík jeden s klecema a to jsme prodávali. [...] Nastoupil jsem do učiliště MHR01 Cheb Koželužská 21 a to byl klášter kousek vedle hřiště Lokomotivy Cheb a já jsem od 14 let od svých rodičủ neviděl ani halîr (hrdě). (narátor Václav Novák, 1. 6. 2019)

Tíživá finanční situace narátora Václava Nováka a jeho rodiny po rozvodu rodičů ho vedla $\mathrm{k}$ tomu, aby pracoval a snažil se pomoci matce. Po celý čas vyprávěl o této době $v 1$. osobě plurálu „my jsme makali, starali se“, jelikož byl matce oporou, což vyústilo v hrdost na svá učňovská léta, kdy se dokázal sám uživit a od rodičů tak „neviděl ani halîr“"

Úvodní části vyprávění věnovali narátoři klimatu v rodině, jež bylo jakousi vstupní bránou do jejich života. Narátorům díky úkolům $v$ domácnosti se vštěpovala povinnost a schopnost plnit různě obtižné cíle, za něž nesli zodpovědnost. Fenomén zodpovědnosti nicméně neprezentovali homogenně, ale důvody byly rozličné. Jednalo se o dvě spektra, která můžeme definovat jako časovou vytiženost rodičů a ztráta matky, nebo otce.

\section{Dominantní rodič ve vyprávění}

Při analýze orálně-historických rozhovorů s členy OF Znojmo hrál jeden rodič určitým způsobem při výchově dominantní roli. Bylo Ihostejno, zdali se jednalo o matku, nebo otce, ale narátoři vymezovali ve svém vyprávění větší prostor osobě, která na ně při socializaci více působila. Takhle se projevila úloha matky ve vyprávění narátora Jaroslava Kachny, který původně vyprávěl historku o školní rvačce se spolužákem, aby navázal ve vzpomínání na svou matku:

Narátor Jaroslav Kachna: Jinak hlavně samozřejmě na ty mé názory měla vliv zejména teda moje mamka, která nám všem vykládala, jak probíhalo osvobození v [roce 19]45, jak se okolo znásilňovalo, jak jim říkali, že nějaký německý důstojník, at’ všichni hlavně dcery zavřou důkladně a [...] schovají [...] stejně tak i ty okolnosti okolo [roku 19]48, plus teda potom ty padesátý léta, takže jako já jsem od malička věděl, že jsou určitý věci, který ve škole nesmím říkat, protože bych z toho mohl mít problémy. 
Zerbst Jan: To se vaši rodiče, nebo respektive mamka nebála, že byste se prořekl?

Narátor Jaroslav Kachna: Jako asi se tolik nebála, protože nám všem hlavně říkala, todle nesmíte nikomu říkat, todle když někomu řeknete, tak mě zavřou a vy půjdete do [dětskýho] domova. Toho jsme se mi všichni báli víc. Proto jsme spíš byli zticha, věděli jsme, že to co nám řeknou ve škole, že prostě musíme brát jaksi s rezervou. [Matka nám říkala:] ,Samožrejmě paní učitelce můžete věřit v matematice, nebo př́rodopise, ale ve věcech, když se budete učit o historii, nebo tak, tak to vám když tak podám já, jak to bylo.' (narátor Jaroslav Kachna, 16. 6. 2019)

Slovní obrat „nesmíte nikomu říkat“ nám otevírá pomyslnou vnitřní disidentskou činnost rodiny. Tím nemyslím, že by se její členové stavěli aktivně vưči komunistickému režimu, ale nepřijali jeho symbolický svět, v němž žili a udržovali si tak vlastní vnímání společenského dění. Narátor Jaroslav Kachna tedy od útlého věku byl utvrzován matkou v nedůvěře vưči oficiálnímu socialistickému diskurzu, když se mluvilo o humanitních vědách, zejména pak historii. Pokud narátor zmiňoval, že informacím o historii nelze věřit, je nutné pochopit proč. Tehdejší socialistická historiografie měla za úkol se odříznout od předúnorové historiografie. Nemůžeme říci, že se jednalo o jednotné období, minimálně mezi lety 1950 až 1970 můžeme díky Vítězslavu Sommerovi (2012: 56-428) detekovat tři období socialistické historiografie: zakládající stalinistické období, kritické vnímání soudobé historiografie po smrti Stalina a reformní. V symbolickém světě nicméně k revizi hlavních symbolů komunistického režimu, jakým byl například Vítězný únor či úloha dělníka a jejich historické interpretace, nedocházelo, protože plnily legitimizační funkci socialistického zřízení. S tímto se rodina narátora Jaroslava Kachny nikdy neztotožnila, a proto mu matka vštěpovala, že fakta o historii získaná ve škole „musíme brát jaksi s rezervou“.

Významnou úlohu matky, o níž se může člověk opřít, popsal i narátor Pavel Babula, protože zajištovala chod rodiny, chodila na rodičovská sdružení, opečovávala 4 sourozence, pomáhala s usedlostí a prarodičům. Děti tak u oné ženy nalézaly oporu, proto ji narátor Pavel Babula připodobnil k „přístavu“.

Moje maminka se starala o rodinu, to byl takový př́stav. A to je pořád, že jo. (narátor Pavel Babula, 7. 2. 2017) Tat'ka ten byl takovej svéráz, on byl traktorista a potom dělal posunovače na dráze. (narátor Pavel Babula, 7. 2. 2017)

Narátor Václav Novák procházel socializací s dominantní rolí otce, ačkoliv se s narátorovou matkou rozvedl a otec se synem žili odděleně. Otec narátora Václava Nováka sice patřil mezi zakládající členy KSČ, ale to mu nezabránilo přicházet do konfliktu se stranickými kolegy. Silně to Ize vyčíst ve dvou př́bězích. První popisoval nespravedlivé jednání Státní bezpečnosti (dále jen StB) při fyzickém nátlaku na malorolníka, aby podepsal vstup do jednotného zemědělského družstva (dále jen JZD).

Narátor Václav Novák: Jednak můj otec byl tenkrát komunistou a měl tři místný číslo legitimace tenkrát.

Zerbst Jan: Počkat, co to znamenalo?

Narátor Václav Novák: Každá legitimace byla číslovaná, takže on byl jeden z těch 
zakladatelů komunistů. No a, vedle nás bydlel tenkrát takovej sedlák, kterej nechtěl vstoupit do statku, do družstva nic. Tak tam přijeli StBáci. [...] Přijeli k němu a ted'kom jsme slyšeli křik a nářek, tak jsme nahlídli tam mezi vratama a viděli jsme, jak voni ho přivázali k vratům, jo, a kopali ho mezi nohy a bili ho tam, aby podepsal tu přihlášku a já jsem utíkal za tátem. Povídám: „Táto, podívej se, souseda tam bijou.“ Tata vzal pistoli, měl doma pistoli ilegálně drženou ještě z války. Vlítl tam a povidá: „Parchanti, nechte ho být, nebo vás postřilím jako psi.“" (dưrazně) Tak [oni] přestali. Pustili toho člověka a na druhej den přijeli StBáci, jo. On [otec] že musí odevzdat zbraň, [...] ale toho souseda začali šikanovat a potom mu zapálili statek a umřela mu tam celá rodina a on tam zůstal sám. (vzlyky) Naši ho vzali k nám do baráku a bydlel u nás. A na našeho tatu naléhali, aby ho vyhnal ven, ale táta řekl, ne, že to je jeho kamarád a že mu poskytne veškerou pomoc (důrazně). (narátor Václav Novák, 1. 6. 2019)

Obsah příběhu se vztahuje ke kolektivizaci zemědělství. Ta probíhala v období let 1949 až 1960. Podle historičky Jany Burešové (2013: 24) šlo z pohledu KSČ o destrukční proces tradičního života na venkově a rolnictví. Pilîrem se stalo zakládání JZD, díky čemuž se zaváděl centrálně administrativní systém řízení zemědělství. Středobod příběhu leží v mravním imperativu, poněvadž otce vykreslil jako člověka, jenž bránil druhého před bezprávím nehledě na svou osobní újmu. Slova „křik“, „nářek“ a „bili“, která volil pro popis př́běhu útoku StB na sedláka, jsou vyplněny emocemi. Ukazovalo se, že narátorův otec je schopen ustát tlak představitelů KSČ, kdy malorolníkovi nabídl přístřeší se zdůrazněním, že mu „poskytne veškerou pomoc“. Zároveň je zde vidět i jistá impulzivita v jednání ve výhružce členům StB: „postř̌lím jako psi“.

Ona impulzivita v narátorově vyprávění se otiskla i v druhém příběhu, který souvisel opět s otcem a komunistickou perzekucí. $V$ té době se narátorův otec $s$ matkou rozvedl a přestěhoval se do Rotavy u Sokolova, kde pracoval ve firmě Vespo.

Narátor Václav Novák: Když byla výroční schůze, tak do menších podniků jezdili na výroční schůze zástupci z partaje, když to byl malej podnik, tak tam chodili z okresů a když to bylo nad 15 tisíc zaměstnanců, tak tam chodili z Národního shromáždění. Otec, když tam přišel, poznal v tom jednom poslanci člověka, který za války kolaboroval s gestapem a do konce dopomohl i k zatčení a zabití jednoho člověka, kterej utíkal před gestapem, že ho srazil na zem a gestapáci ho chytli a zastřelili na místě. Tak šel [táta] za řídícím schůze a vyžadoval si, aby mohl promluvit ještě dřív (důraz) než bude zahájená schůze a [oni se divili,] co tam chce říct! A on povídá: „To vám neřeknu, to musím říct já do mikrofonu, jo. Jestli mně to nedovolíte, tak potom já vystoupím okamžitě z komunistické strany jako komunista.“ (zrychlený rozhněvaný hlas) Oni se radili chvilku a potom řekli: „Tak jo.“ Otec řekl dosti tvrdě. (důraz) Pokud takoví kurvy bolševický budou ve vládě, že on jako komunista tam nemá co dělat.

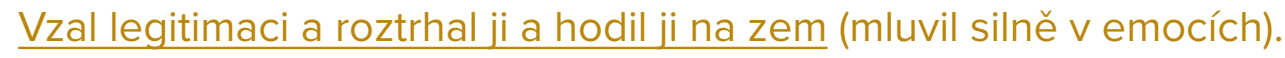

\section{Zerbst Jan: Jenom můžu, to byla Rotava u Sokolova?}

Narátor Václav Novák: Jo, jo, on byl ve Vespu, tam dělali nějaký dvoukolový káry a on otec $v$ tý době tam navlíkal pneumatiky na ty kola. Oni z Německa objednali nějakou mašinu, která to dělala automaticky, jo. Nakonec potom, když udělali konfrontaci a postavili k mašině mýho taty [, tak] on měl takovou rutinu v tom, že on udělal víc, než ta mašina za spousty tisíc a na základě toho byl navrženej na Řád práce, [...] ale to 
bylo právě před tady tímdle tím vystoupením. Ale samozřejmě místo Řádu práce, tak ráno, když šel do práce, šel k píchačkám, tam stáli tři fešáci v koženejch kabátech a oni ho neznali, nevěděli, kdo to je, ale věděli, jaký má číslo píchačky, jak šáhl na píchačku, dostal pažbou pistole do hlavy zezadu. Rozbili mu hlavu. No a my jsme ho sedm let neviděli. Bez soudu (dưraz) byl nejdřív na Borech v Plzni a potom byl v Jáchymově v uranových dolech. (narátor Václav Novák, 1. 6. 2019)

V prríběhu narátora opět akcentuje pojetí morálky otce, který se postavil nespravedlnosti z minulosti, kdy vnímal poslance Národního shromáždění jako nacistického kolaboranta spolupracujícího s nechvalně proslulou Geheime Staatspolizei, lidově gestapo. To hrálo ústřední roli v pronásledování komunistů, náboženských uskupení, Židů a pestré palety oponentů nacistického Německa. Konkrétně také organizovali transporty do koncentračních táborů či masově vraždili civilní obyvatelstvo ve Svaz sovětských socialistických republik (McDonough, 2016: 228). Aby tak zdůraznil morální selhání poslance, vykreslil jej slovesem „dopomohl“ a substantivy „zatčení“, „zabití“. Narátor Václav Novák dával impulzivní chování najevo pokaždé, když se domníval, že se někdo nechová čestně. Ústřední roli zde hrála i stranická legitimace, symbol příslušnosti ke KSČ, protože otec demonstrativně „vzal legitimaci a roztrhal ji a hodil ji na zem“. Za povšimnutí stojí, že tyto pasáže pronesl v tak silných emocích, že zaměnil pojem „bolševický“ za nacistický. Během rozhovoru pak výraz bolševismus či gestapo používal v expresivním smyslu, pokud cítil křivdu a vykresloval sám sebe jako osobu, jenž se postavila bezpráví.

Zároveň vzor otce můžeme vidět nejen v morálním imperativu, ale také v obrazu manuální zručnosti, jelikož dokázal být rychlejší než drahý stroj a „udělal víc, než ta mašina za spousty tisíc“, za což mohl obdržet ocenění Řád práce.

Přestože otec narátorky Jany Jiráskové zemřel poměrně brzy, zachovala si na něj mnoho vzpomínek, jež jsou spojeny s odvahou a politickou profilací.

I když byl v Bezkově za války celkem klid, přece jsem silně vnímala všeobecný strach. Tatínek byl jako [ruský] legionář v odboji a v úkrytu na pưdě měl i nějaké zbraně. O těch za války nevěděla ani maminka, ale i tak se o tatínka bála. Když uslyšela auto, utíkala k oknu, jestli nejede gestapo a nezastavuje před školou. Tatínek také zorganizoval pro celou obec mletí načerno. (Paměti narátorky Jany Jiráskové, s. 5)

V jejích vzpomínkách se dochovaly emoce strachu o vlastního otce z období 2 . světové války. Jeho činy, jež ohrožovaly nejen jeho, ale i celou rodinu, tak probouzely nejistotu a strach, což narátorka umocnila slovy „všeobecný strach“ a „utíkala“. Necelé tři roky poté přišel 25. únor 1948, kdy narátorce bylo 11 let a zde mohla sledovat postoje svého otce, ruského legionáře.

Velmi dobře si pamatuji na atmosféru, která u nás tehdy zavládla. V obývacím pokoji stále puštěné rádio, tatínek zamračený, odbýval mě, na což jsem nebývala zvyklá. Maminka mě odváděla do sousední kuchyně a říkala, že nesmím tatínka rozčilovat. Když jsem se ptala, co se děje, dozvěděla jsem se, že komunisti by nás chtěli prodat Stalinovi, ale Beneš to nedovolí. Pak napětí skončilo - „Beneš to dovolil“ - Tatínek to těžce nesl až do své smrti v listopadu téhož roku. Teprve mnohem později jsem se dozvěděla od maminky, že krátce před smrtí prohlásil asi toto: „Bude to hodně zlé a bude to trvat asi 20 let. Ale nakonec se z toho dostaneme." Maminka pak v roce 
1968 vzpomínala na otcův odhad doby, kdy dojde ke změně. (Paměti narátorky Jany Jiráskové, s. 7)

V tomto př́běhu je do středobodu vystaven postoj k 25. únoru 1948. Mladická narátorka nechápavě sledovala podrážděnost jejího otce. Nechápala, proč se u otce projevovala naštvanost, což zdůraznila adverbiem "těžce“ a verbem „nes|“. Ten nesouhlasil s komunistickým převzetím moci v Československu, které se definitivně stalo satelitem Sovětského svazu. Za zmínku stojí i důvěra vkládaná do prezidenta Edvarda Beneše, kterého vnímal jako pomyslnou hráz demokracie. Demokratičtí ministři podali demisi 20. února 1948 v rozmezí mezi 12. až 19. hodinou (Kaplan, 2018: 67-69). Bezprostřední př́činou se stal neúspěšný pokus odvolat rozhodnutí ministra vnitra, komunisty Václava Noska, učinit kádrové změny velitelského sboru SNB ${ }^{2}$ Praha. Vytvořili tak politický tlak na prezidenta Beneše. Ten nátlaku neodolal a překvapivě demisi ministrů príjal a podepsal doplnění vlády podle Gottwaldových představ. Podle historika Václava Vebera se jednalo o Benešovo pochybení, poněvadž jeho ústavní povinností bylo za této situace rozpustit vládu jako celek a 1) pověřit Gottwalda jako předsedu největší strany podle výsledku posledních voleb, aby s ostatními stranami vyjednával o vytvoření nové vlády, anebo 2) vypsat nové volby (Veber, 2009: 7-9). Z toho důvodu pronesl otec narátorky J. Č. v rozhořčení větu: „Beneš to dovolil“. Narátorka Jana Jirásková tak v raném dětství poznala chování dominantního rodiče, který jí předestřel antikomunistické postoje.

Vykreslování rodinného zázemí a pěstování fenoménu zodpovědnosti rozvinuli narátoři ve svém vyprávění pomocí jednoho dominantního rodiče, jenž jim udával vzorové vzorce chování. Otevíraly se jim také první zkušenosti s komunistickým režimem prostřednictvím rodičů, kteří s ním přicházeli do prvních konfliktů a oni tak byli poprvé negativně konfrontováni s restriktivní povahou komunistického režimu. Nejpregnantněji šel tento fenomén vystopovat u narátora Václava Nováka, jenž emotivně popisoval příběh bezpráví o uvěznění jeho otce bez soudu, z čehož rezultovala i práce $v$ uranových dolech.

\section{Fenomén mentoringu}

Prvním příkladem mentoringu v praxi, bude vzpomínka narátora Jaroslava Kachny, který si vzpomínal na výraznou roli prarodiče a strýce z matčiny strany. Následující prezentovaná vzpomínka vzešla z mého podnětu, poněvadž jsem se potřeboval ujistit, jestli jsem dobře porozuměl vyprávění.

Zerbst Jan: Vlastně díky mamince a tátovi [jste se] dostal k samizdatové literatuře, jestli to chápu dobře.

Narátor Jaroslav Kachna: Spiś jako nepř́mo, ještě to jsem neřekl, moje mamka měla bratra emigranta ve Švýcarsku a moji prarodiče, ze strany mamky, tam občas jezdili.

Zerbst Jan: To byli ti nakladatelé?

Narátor Jaroslav Kachna: Ano, oni tam občas jezdili a přivezli občas nějakou

2 Sbor národní bezpečnosti. 
právě zakázanou literaturu, konkrétně si pamatuju, že nám dovezli od Mlynáře „Mráz přichází z Kremlu“ a Škutina „Presidentův vězeň“ a „Na hradě plném bláznů [presidentův vězeň]“. (narátor Jaroslav Kachna, 16. 6. 2019)

Osoby, o nichž se zmiňuje narátor Jaroslav Kachna, jsou natolik významné, že je potřeba pro dokreslení reality obě představit. Narátorův dědeček z matčiny strany byl významný brněnský meziválečný nakladatel Jan V. Pojer, jenž se proslavil vydáváním edice krásných knih Atlantis (paralelně pracoval i jako úředník), jimž se dostávalo povolaného uznání od nejpřednějších prvorepublikových odborníků, jakým byl Arne Novák, Karel Čapek, nebo František Xaver Šalda (Kudrnáč, 1997: 103). Po 25. únoru 1948 byl propuštěn z úřednické funkce a jeho nakladatelství přestalo existovat. Narátorův strýc, Jiří J. Pojer, pro změnu se vůči komunistické straně vymezoval hned od počátku jejího převzetí moci. Kupř́ḱladu vylepoval po Brně protikomunistické letáky. Následně vstoupil v 60. letech do tajných církevních struktur, pro něž prováděl konspiraci (Pojer, 2007: 18-20), a stal se i vysvěceným biskupem tzv. skryté církve (narátor Jaroslav Kachna, 16. 6. 2019), aby na počátku normalizace emigroval do Švýcarska, protože mu hrozilo zatčení (Pojer, 2007: 21). Nespokojenost a trpké zkušenosti narátorova dědečka a strýce vyústila v distribuci exilové literatury do Československa, kterou si mohl narátor Jaroslav Kachna prečíst. Všechny tři knihy vykreslovaly komunistické panství jako neschopné, ačkoliv z jiného úhlu pohledu. Zatímco Škutinovo dílo vykresluje černým humorem životní zkušenosti $s$ autorovým vězněním pod hlavičkou politický vězeň, přestože tento termín $v$ tehdejším Československu oficiálně neexistoval (Škutina, 1990). ${ }^{3}$ Dílo Mráz přichází z Kremlu z pera Zdeňka Mlynáře (2018), jež vykazovalo taktéž silné biografické rysy, poněvadž se v této knize vyrovnával se svou minulostí pod vlivem stalinismu, nastínilo pozadí turbulentního období Pražského jara. Všechny knihy, které formovaly narátora, vykreslovaly život na východ od ašského výběžku v negativních barvách. Cestu k nim mu otevřeli právě dědeček se strýčkem.

Rozširrená rodina vedla narátora Kryštofa Práška k odpovědnosti, fenoménu, jenž jsem rozebíral v oddílu „Rodina jako formující faktor pro fenomén zodpovědnosti“. Letní prázdniny trávil během svého mládí u príbuzných na vesnici.

\section{Moje dětství bylo, dá se říct, idylické [...] Ovšem my jsme každej rok jezdili pracovat o žních k těm mejm venkovskejm předkům a tam já jsem prostě zažil ještě ten nádhernej stav, kdy prostě ten statek obsahoval veškerý zvî́ectvo od koní, dobytka, prasat, slepic, kuřat, kačeny, husy, neuvěřitelný, že jo, nádherný. A ted' ta jejich činorodá práce, jo. To si prostě dneska člověk nedovede představit, jak to bylo kouzelný, mně se to hrozně líbilo. My jsme museli tvrdě makat, hlavně o žních jsme prostě, jsme prostě uklízeli slámu. (narátor Kryštof Prášek, 3. 3. 2019)}

Formování zodpovědnosti zde vycházelo z narátorovy zkušenosti, kdy pracoval na vesnici o žních. Pro vykreslení života na vesnici tak používal přídavná jména „idylické“, „nádhernej“ a „kouzelný“. Tato zkušenost znamenala, že „museli tvrdě makat“, což ovšem nijak negativně nepojímal, naopak bral tuto zkušenost pozitivně a k př́ibuzným pocitoval

3 Z dvou Škutinových knížek jsem četl pouze druhou jmenovanou, proto i stručný obsah vychází z oné knihy. 
vděčnost.

Př́běh narátora Břetislav Jonáš neobsahoval přímo mentory, nicméně objevovali se v jeho vyprávění tzv. významní druzí, jež ho ujištovali v jeho ideovém ukotvení a jisté nesnášenlivosti vưči KSČ.
Já jsem nastoupil [ve Znojmě] do Okresního průmyslového podniku, což byl podnik, který řídil okresní národní výbor, čili tam byl nějaký politický vliv, ale naštěstí můj ředitel byl bývalý Baták a on [...] si mě oblíbil. Vždycky když jsme byli [spolu sami]: „Stando, pocem, víš, jak to bylo u Batě.“ Tak on byl diverzant, takže měl takovou jakoby ochrannou ruku nade mnou (smích). (narátor Břetislav Jonáš, 19. 4. 2019)

Tato zprostředkovaná zkušenost utvrzovala narátora v jeho negativním nazírání na komunistické panství, kdy sice musel dodržovat jeho symbolický svět, ovšem vnitřně s ním nesouhlasil, v čemž ho právě jeho nadřizený utvrzoval. Samotný nadřízený zde hrál úlohu člověka, jenž sice pomáhal „budovat socialismus“, avšak zároveň stále vzpomínal na práci pro Tomáše Bati, významného prvorepublikového československého podnikatele, který vybudoval celosvětově známou obuvnickou firmu a pozvedl menší Zlín v moderní město (Cekota, 2004: 119-224). Tento rozpor podtrhl narátor Břetislav Jonáš ve vyprávění slovem „diverzant“.

Ačkoliv otec narátora Filipa Špičáka byl silně zainteresován v KSČ i jako člen Sboru národní bezpečnosti, v narátorově životním příběhu hrál významnou roli dědeček.

On byl členem sociální demokracie. To mě potom přivedlo do tý sociální demokracie taky podvědomě. (narátor Filip Špičák, 9. 6. 2019)

Narátor Filip Špičák byl po celé období komunistického režimu striktně apolitický, jeho následný vstup v roce 1989 do OF měl jepičí život. Sám zpětně to hodnotil tak, že dědečkovo politicky angažované chování ho „podvědomě“ „přivedlo“ do obnovené Československé sociální demokracie, ačkoliv ve volbách by měl dle svých slov větší šanci na úspěch za OF.

Narátor Pavel Babula přisoudil taktéž významnou úlohu ve formování své osobnosti svým prarodičům, zejména pak pradědečkovi, který během 1. světové války bojoval na italské frontě, kde padl do zajetí 28. srpna 1917 v Canale. Svou přihlášku do nově tvořících se legií podal 17. dubna 1918 v Padule. ${ }^{4}$ (Československá obec legionářská, číslo 31561) Během této asi šestiminutové pasáže jsem téměř nevstoupil do narátorova vyprávění, a naopak jsem pouze naslouchal.

V tom dětství si strašně vzpomínám na babičku a na dědečka, protože ti mě formovali nejvíc. Dědeček jako starý legionář za 1. světové války mi vykládal ty válečný příběhy, kdy se to v podstatě nesmělo vykládat, nebo Masarykovi, v podstatě zažehnul jiskru k historii a dějepisu. [...] Já jsem byl prostě vychovávanej k tý lásce k Československu a tomu Masarykovi. A dědeček měl ten [legionářský] mundur schovanej a to se

4 Projekt Československé obce legionářské měl za cíl zpopularizovat úlohu československých legionářů na vzniku státu a také vznik databáze legionárư (Československá obec legionářská). 
nesmělo vytahovat v podstatě [a] on o tom mluvil, třeba jsme seděli u kamen, ale jinak se o tom nebavil, to bylo tabu. Oni bojovali za Masaryka, ta idea pro ně byl Masaryk, nebo Štefánik. On byl v Neapoli, bojoval na Piávě a tam bojoval v podstatě na rakouský straně. Potom když se tam ty legie zformovaly, tak bojoval zase na italský, jakoby proti rakušákům. [...] Oni je nemohli zatknout, nebo zajmout [ty] legionáře na tý italský straně, protože rakousko-uherská armáda [je] hned střílela bez soudu. (narátor Pavel Babula, 7. 2. 2017)

Mentorská úloha dědečka narátora Pavla Babuly spočívala ve vyprávění o významných osobnostech československých dějin a zkušenostech z Velké války. Prarodič díky tomu „zažehnul“ narátorovu lásku k dějinám. Narátor je dodnes milovníkem historické prózy i odborné literatury. ${ }^{5}$ Samotné narátorovo zdůraznění lásky k Československu má hlubší kořeny, jelikož dodnes se identifikuje jako čechoslovakista, což několikrát i během rozhovoru zdůraznil. Dědečka vnímal jako hrdinu, protože zajetí by znamenalo jistou smrt kvůli dezerci, a proto zdůraznil, že by armáda Rakousko-Uherska „hned střílela bez soudu“. Děda mu svým vyprávěním navíc zprostředkoval pomyslného mytologického hrdinu, kterým byl pro oba dva Tomáš Garrique Masaryk, který v zahraničí za 1. světové války formoval ideje čechoslovakismu a rozpadu Rakousko-Uherska (Kosatík, 2018: 202275). Narátorův děd vykládal o Masarykovi narátorovi Pavlu Babulovi v samých superlativech, takže legionáři v jeho vyprávění „bojovali za Masaryka, ta idea pro ně byl Masaryk“ a vznik samostatného státu spojil symbolicky s prvním československým prezidentem.

Masarykem jsem tedy vstoupil na břeh pomyslných mytologických hrdinů, tedy osob, které neměly přímý kontakt s narátorem, ale byly do životního příběhu narátora zakomponovány na základě mytologického vyprávění, jak by jej definoval religionista Joseph Campbell. Samotný mýtus má v zásadě čtyři funkce: mystickou - pomáhá nám pochopit, jaký je vesmír zázrak; kosmologickou - ukazuje nám, jaký má vesmír tvar; sociologickou - podporuje a zhodnocuje určité společenské uspořádání; pedagogickou - ukazuje, jak prožít plnohodnotný život. Joseph Campbell se dále zamýšlel nad mytickými postavami, které u lidí vstupují do procesu mytologizace. Jednalo se o osoby, které bychom mohli nazvat taktéž mentory (významní druzi), protože jedince vychovávali pro život. Campbell mytologického hrdinu definoval tak, že ona postava objevila, nebo vykonala něco, co se vymyká normálním lidským schopnostem a běžné zkušenosti. Hrdina je někdo, kdo obětoval život něčemu většímu, než je on sám, nebo přináší pak ostatním lidem nějaké významné poselství (Campbell, Moyers, 2016: 40-161).

Toto Ize nejlépe ilustrovat na příkladu narátora Vladimíra Zatloukala, který ve svém vyprávění přidělil mytologickou úlohu mentoringu prarodičům. Ve svém př́iběhu předestřel život svého dědečka, který po únoru 1948 přišel o majetek, jenž započal postupně chátrat, a proto dostal část svého majetku do správy.

Dědeček vybudoval rodinný hospodářství, kde s babičkou měli jednu kravku a posléze vybudovali dům, postavili dřevěnici, pak postavili hospodu, obchod. Začali hospodařit, koupili nějaký pozemky a v podstatě v tom [roce 19]48, kdy veškerej majetek dědovi a babičce sebrali, tak měli dvacet krav, x kusů koní, bryčky, několik

5 Viz narátorova knihovna, kde dominují autoři jako Vlastimil Vondruška, nebo Christian Jacq. 
stodol a hospodu, kde byl i obchod s potravinami. [...] Náš majetek, na kterým my jsme celá rodina dřeli, tak dostali ti největší lumpové z vesnice, kteří se dali ke komunistům. Jeden dostal stodoly a dědovu bryčku. Ten [děda] když viděl tu hrůzu, co se děje s tím majetkem, tak prostě kolikrát hořce plakal a nakonec to dopadlo tak, že asi za tři roky, ten co dostal hospodu, tak tam udělal obrovský manko. Ten co dostal obchod, tak ho přivedl na buben. Takže přišli za dědou a řekli, že bude dělat vedoucího. Jeho to nebude, ale může to vést. Děda na to zareagoval spontánně a já si myslím, že byl št’astnej, že se to nerozpadne. (narátor Vladimír Zatloukal, 25. 9. 2019)

V úryvku můžeme sledovat, že narátor ve svém vyprávění vykreslil život svého dědečka, který se svou pílí vypracoval v prosperujícího člověka, jenž začínal hospodařit jen se skrovným majetkem, který se postupně rozrůstal, a jehož ztráta jej po roce 1948 nepoznamenala. Naopak byl rád, že se může opětovně o něj starat, což se projevovalo citově zabarvenými slovy „hrůzu“, „hořce plakal“, „štastnej“.

Narátor Vladimír Zatloukal popsal podobný př́běh i ve vztahu k dědečkovi z matčiny strany. Ten se přistěhoval do Československa v roce 1945 z Rumunska do příhraniční vesnice Šanov v okrese Znojmo do domu po vysídleném Němci.

Můj děda z maminčiny strany, oni se přestěhovali z Rumunska v [v roce 19]45, dostali v pohraničí v podstatě nějakou nemovitost a děda můj, kterej byl obrovskej národovec, tak se přihlásil, že by se chtěl přestěhovat. [...] Dostal nějakej ten výměr [...] a na té usedlosti ještě bydlel ten Němec. [...] Děda přijel s dětma. Ten Němec povídá: „Jo, já jsem připravenej vám v podstatě to předat tady.“ Děda říká: „Moment, takhle to nebude, bude to jinak. Jedeme na státní notářství do Mikulova, tam dáme dohromady soupis majetku, movitýho i nemovitýho a já to od vás koupím, já vám to zaplatím.“ Ten můj děda byl chodící spravedlnost, já si ho pamatuju. Prostě takový to jeho nečiň druhému, co by vadilo tobě. (narátor Vladimír Zatloukal, 25. 9. 2019)

Divoké retribuční období přineslo mnoho nespravedlivých činů. Samotné období protektorátu bylo jako nevybuchlá sopka. Národ žil po celou dobu myšlenkou na pomstu a jakékoliv pokusy o mentorování jen rozdmýchávaly vášně. Politici podporovali divoké retribuce jako prostředek k maximalizaci počtu odcházejících Němců a minimalizace počtu těch, které pak bude nutno deportovat organizovaně (Frommer, 2010: 61-63). O tomto období byl inkriminovaný úryvek narátora Vladimír Zatloukal při našem rozhovoru. Jeho dědeček z matčiny strany je zde opět vykreslen jako člověk pevných mravů, který při zjištění, že by odsunutý Němec měl odejít bez peněžní náhrady, rozhodl se s ním vydat do Mikulova, kde u notáře provedli soupis majetku, který následně narátorův dědeček všechen odkoupil, a tak jej považoval za „chodící spravedlnost“.

Úloha mentorů vyplnila ve vyprávění narátorů nezastupitelné místo, protože spolu s rodinou utvářeli jejich postoje. Narátoři své mentory shledávali jako autority, které jim otevírali morální vzorce jako v případě narátora Vladimíra Zatloukala a jeho dědečků, nicméně nezastupitelné byly zde i světonázorové ideály reprezentované významnými prvorepublikovými osobnostmi stojící za vznikem Československa a jejich rozkvětem. 


\section{Závěr}

Analýza subjektivní reality členů OF ve Znojmě nám ukázala několik obecných poznání, které mají narátoři společné. Významný a všeobjímající pro všechny narátory byl fenomén zodpovědnosti, jenž jim rodiče vštěpovali pomocí domácích povinností, které narátoři museli plnit. Význam zodpovědnosti nicméně mohli podporovat i významní druzí, jako jsme mohli vidět v případě narátora Kryštofa Práška, který trávil letní prázdniny u svých př́buzných na vesnici v období žní. Rodina byla také prvním místem, kde se malým narátorům vštěpoval nesoulad mezi objektivní realitou socialismu a subjektivním kosmem rodiny. Tuto úlohu jim zprostředkovával obvykle jeden z rodičů, ačkoliv paleta vlastností, jež rodiče symbolizovala, byla mnohem širší. Úloha mentoringu pak spočívala v potvrzení symbolického světa, jež nesouzněl se socialistickým univerzem. Sami narátoři přebírali za své vyprávění o mytologických hrdinech, kteří museli vykonat mimořádné skutky, či postavit se nepřízni osudu.

\section{Referencie}

Berger, P. a Luckmann, T. (1999). Sociální konstrukce reality: pojednání o sociologii vědění. Brno: Centrum pro studium demokracie a kultury.

Brumovská, T. a Seidlová, G. (2010). Mentoring: výchova k profesionálnímu dobrovolnictví. Praha: Portál.

Burešová, J. (2013). Problematika výzkumu dějin kolektivizace v Československu a v České republice. In J. Rokovský, L. Svoboda (Eds.), Kolektivizace v Československu (s. 24-31). Praha: Ústav pro studium totalitních režimů.

Campbell, J. a Moyers, B. (2016). Síla mýtu. Praha: Argo.

Cekota, A. (2004). Geniální podnikatel Tomáš Bat’a. Zlín: Univerzita Tomáše Bati.

Čermák, I. (2004). Narativní myšlení a skutečnost. Československá psychologie, 48(1), 17-26.

Československá obec legionářská. (b. d.). Herman Petr. Legie 100. Získané 23. 6. 2021, z http://legie100.com/krev-legionare/31561/.

Frommer, B. (2010). Národní očista: retribuce v poválečném Československu. Praha: Academia.

Chrz, V. (2007). Možnosti narativního př́stupu v psychologickém výzkumu. Praha: Psychologický ústav AV ČR.

Jonas, H. (1997). Princip odpovědnosti: pokus o etiku pro technologickou civilizaci. Praha: Oikoymenh.

Kaplan, K. (2018). Únor 1948: komentované dokumenty. Praha: Epocha.

Kosatík, P. (2018). Jiný T. G. M. Praha: Tympanum.

Kraus, B. (2001). Člověk, prostředí, výchova. Brno: Paido.

Kudrnáč, J. (1997). Pojerova Atlantis. Sborník prací Filozofické fakulty brněnské univerzity: řada literárněvědná, 46(44), 103-115. 
Matoušek, O. (2003). Rodina jako instituce a vztahová sitt. Praha: Sociologické nakladatelství.

McDonough, F. (2016). Gestapo: mýtus a realita Hitlerovy tajné policie. Praha:

Vyšehrad.

Medick, H. (1994). Mikro-Historie. In W. Schulze (Ed.), Sozialgeschichte, Alltagsgeschichte, Mikro-Historie (s. 40-48). Göttingen: Vandenhoeck und Ruprecht.

Možný, I. (2006). Rodina a společnost. Praha: Sociologické nakladatelství.

Mlynáŕ, Z. (2018). Mráz přichází z Kremlu. Praha: Zed’.

Petrusek, M. (1999). Velký sociologický slovník. Praha: Karolinum.

Pojer, J. J. (2007). Jeden z útěků přes železnou oponu: vzpomínky Jiřího J. Pojera, 2. část. Proglas, 18(2), 18-21.

Schütze, F. (1983). Biographieforschung und narratives Interview. Neue Praxis, 13(3), 283-293.

Sokol, J. (2010). Etika a život: pokus o praktickou filosofii. Praha: Vyšehrad.

Sommer, V. (2012). Angažované dějepisectví. Praha: Nakladatelství Lidové noviny.

Škutina, V. (1990). Prezidentův vězeň na hradě plném bláznů. Praha: Naše Vojsko.

Štěpek, J. (2008). K př́dělovým systémům 20. a počátku 21. století. Ekonomická revue, 11(4), 21-23.

Vaněk, M. a Mücke, P. (2011). Třetí strana trojúhelníku. Praha: Fakulta humanitních studií UK v Praze.

Veber, V. (2009). Jak to bylo s demisemi v únoru 1948. Pamět’ a dějiny, 4(1), 7-9. 